\title{
Activity of endo-polygalacturonases in mirid bugs (Heteroptera: Miridae) and their inhibition by plant cell wall proteins (PGIPs)
}

\author{
Francesca FRATI ${ }^{1,3}$, Roberta GALLETTI ${ }^{2}$, Giulia DE LORENZO ${ }^{2}$, GianANDRea SALERNO ${ }^{1}$ and ERIC CONTI ${ }^{1 *}$ \\ ${ }^{1}$ Dipartimento di Scienze Agrarie e Ambientali - Entomologia, Università di Perugia, Borgo XX Giugno 74, 06121 Perugia, Italy \\ ${ }^{2}$ Dipartimento di Biologia vegetale, Università di Roma "La Sapienza”, Piazzale Aldo Moro 5, 00185 Roma, Italy \\ ${ }^{3}$ Dipartimento di Biologia e Difesa Agro-Forestale - Entomologia, University of Basilicata, Campus di Macchia Romana, 85100 \\ Potenza, Italy
}

Key words. Miridae, Heteroptera, Curculionidae, Coleoptera, endo-polygalacturonase, PG, polygalacturonase-inhibiting proteins (PGIP), plant cell wall proteins, plant induced plant defence, direct defence, saliva

\begin{abstract}
Endo-polygalacturonases (PGs) are hydrolytic enzymes involved in the degradation of pectin, one of the major components of plant cell wall. While PGs from fungi, bacteria and plants have been extensively studied, PGs from insects are much less known, although they are likely to play an important role in insect-plant interactions. Presence of PGs has been reported for both piercing-sucking and chewing insect species, and possibly more commonly in mirid bugs (Heteroptera: Miridae). A screening of some common mirid species and other insects, belonging to different orders and families, was conducted using agarose diffusion assays run at different pHs. All the mirid species tested [Lygus rugulipennis Popp., L. pratensis (L.), Orthops kalmi (L.), Adelphocoris lineolatus (Goeze) and Closterotomus norwegicus (Gmelin)] showed PG activity, mainly at pH 7-8, whereas no activity was recorded for the other insect species, except Sitophilus sp. (Coleoptera: Curculionidae). PG activity in females of L. pratensis was significantly higher than in males, whereas there were no differences between the sexes in the other species. In all these species, PGs were present both in the salivary glands and the gut, with a higher activity in the salivary glands, confirming the role of these enzymes in the feeding behaviour of mirid bugs. Inhibition of mirid PGs by polygalacturonase-inhibiting proteins (PGIPs) from different plant sources was analysed at $\mathrm{pH}$ 7. PGIPs are extracellular plant proteins known for their ability to inhibit fungal PGs and restrict fungal colonization. Two PGIPs from Phaseolus vulgaris (PvPGIP3 and PvPGIP4) inhibited PGs of all the mirid bugs tested. This information may be helpful for the development of innovative insect-resistant plant varieties, for use in low-impact IPM.
\end{abstract}

\section{INTRODUCTION}

Polygalacturonases (PGs; EC 3.2.1.15) are hydrolytic enzymes belonging to the large group of pectinases and involved in the degradation of pectin, one of the major components of plant cell wall. Depending on their mode of action, these enzymes are classified as either endopolygalacturonases (endo-PGs; here referred to as $\mathrm{PG}$ ) or exo-polygalacturonases (exo-PGs). Endo-PGs randomly break the $\alpha 1-4$ glycosidic bonds of pectin, causing cell separation and tissue maceration (De Lorenzo et al., 1997); they also release oligogalacturonides, active as elicitors of plant defence responses (Ridley et al., 2001). The exo-PGs hydrolyze penultimate glycosidic linkages and release digalacturonic acid units (Shen et al., 1996).

PGs occur in pathogens (fungi and bacteria), phytophages (nematodes and insects) and plants. While plant polygalacturonases, as well as other pectinases, are involved in the remodelling of cell wall during plant growth and development, and important processes such as fruit ripening, the polygalacturonases of phytopathogenic fungi and bacteria are important for overcoming the physical barrier posed by the plant cell wall (reviewed by Bellincampi et al., 2004). Among phytophagous animals, the presence of PGs in insects has been known since the late 50s. These enzymes are associated with feeding in both piercing-sucking (Adams \& McAllan, 1956; Laurema \& Nuorteva, 1961; Strong \& Kruitwagen, 1968; Strong, 1970; Miles, 1972; Laurema et al., 1985; Ma et al., 1990; Agblor et al., 1994; Cohen \& Wheeler, 1998; Miles, 1999; Agusti \& Cohen, 2000; Cherqui \& Tjallingii, 2000; Boyd et al., 2002; Shen et al., 2003; D'Ovidio et al., 2004; Shackel et al., 2005) and chewing species (Shen et al., 1996; Doostdar et al., 1997; Girard \& Jouanin, 1999; Shen et al., 2003), and appear to play an important role in insect-plant interactions. PGs are present in species belonging to different insect taxa, but especially common in mirid bugs (Heteroptera: Miridae) (Laurema \& Nuorteva, 1961; Strong \& Kruitwagen, 1968; Strong, 1970; Laurema et al., 1985; Agblor et al., 1994; Agusti \& Cohen, 2000; Boyd et al., 2002; D’Ovidio et al., 2004; Shackel et al., 2005; reviewed by Wheeler, 2001). In nematodes, an exo-PG was cloned from the plant parasitic nematode Meloidogyne incognita (Kofoid \& White) (Jaubert et al., 2002). This nematode PG is probably produced by the subventral oesophageal glands and is also present in the stylets. Its function is thought to be related to the weakening of cell walls of root tissue during nematode penetration and intercellular migration (Jaubert et al., 2002).

Extensive research has revealed that the action of fungal PGs can be specifically counteracted by

\footnotetext{
* Corresponding author; e-mail: econti@unipg.it
} 
polygalacturonase-inhibiting proteins (PGIPs), which prevent fungal invasion and growth in plants (reviewed by De Lorenzo et al., 2001; De Lorenzo \& Ferrari, 2002; Bellincampi et al., 2004). PGIPs are ineffective against bacterial PGs and pectic enzymes of plant origin (De Lorenzo \& Ferrari, 2002). PGIPs are cell wall glycoproteins widespread in flowering plants with great potential for developing of plant resistance to fungi (De Lorenzo et al., 2001). Upon attack by fungal hypha, the control of PG activity by PGIPs favours the accumulation of oligalacturonides (OG) able to elicit defence responses such as phytoalexin accumulation, induction of phenylalanine ammonia lyase (PAL), glucanase, chitinase and lignification (Ridley at al., 2001). OGs may be released not only by exogenous PGs during pathogen infection, but also by endogenous PGs, systemically induced after wounding (De Lorenzo et al., 2001; De Lorenzo \& Ferrari, 2002).

Recent in vitro experiments using both a chewing insect, Diaprepes abbreviatus L. (Coleoptera: Curculionidae) (Doostdar et al., 1997) and the piercing-sucking species, Lygus spp. and Adelphocoris lineolatus (Goeze) (Heteroptera: Miridae) (Conti et al., 2004; D'Ovidio et al., 2004; Shackel et al., 2005), have shown that PGIPs also inhibit the PGs of insects.

In this paper, through an initial investigation on the presence of PGs in several insect pest species of considerable economic importance, belonging to different orders, it is shown that these enzymes are present in both sexes of all the five mirid bugs tested, in a weevil but not in some other species. In mirid bugs, PGs are more abundant in the salivary glands than guts, which confirms the results of previous investigations on other species. Finally, evidence is provided that mirid PGs are inhibited by PGIPs from bean. The significance of these results for the development of innovative insect-resistant plant varieties is discussed.

\section{MATERIAL AND METHODS}

\section{Insects}

PG activity of crop or stored-food pests, belonging to different orders and families, were tested (Table 1) (all specimens tested are deposited in the insect collection of the Dipartimento di Scienze Agrarie e Ambientali, Università di Perugia).

Crop pest species were collected in Umbria, Italy, except for Sesamia nonagrioides (Lefèbvre) (Lepidoptera: Noctuidae), which was collected in Lazio, Italy, and Murgantia histrionica (Hahn) (Heteroptera: Pentatomidae), which was collected in Beltsville, MD, USA. All species were maintained in a controlled-environment growth chamber $\left(25 \pm 2{ }^{\circ} \mathrm{C}, 50-60 \% \mathrm{RH}\right.$ and a photoperiod $14 \mathrm{~L}: 10 \mathrm{D})$. Crop pests were reared in the laboratory using plants or plant shoots, which were replaced three times per week, except for $S$. nonagrioides, which was reared on a meridic diet (Giacometti, 1995).

The two stored-food pests tested were obtained from different sources. Tenebrio molitor (L.) (Coleoptera: Tenebrionidae) was purchased from Esche Grifo (Perugia, Italy) and reared on wheat bran, whereas Sitophilus sp. (Coleoptera: Curculionidae) was kindly provided by Rosa Giacometti, Dipartimento di Entomologia e Zoologia Agraria "Filippo Silvestri", University of Naples, and reared on barley kernels.

\section{PG activity in insects}

For most insect species the presence of PGs was tested on females. However, both sexes were tested in the case of Metopoplax ditomoides (Costa) (Heteroptera: Lygaeidae) and last instar larvae in the case of $S$. nonagrioides and T. molitor, respectively (Table 1). A PG from a culture filtrate of Botrytis cinerea Pers. (Ascomycota: Helotiales: Sclerotiniaceae) was used as a control, because this fungus shows PG activity over a wide $\mathrm{pH}$ range (D'Ovidio et al., 2004).

Only live insects were used in the experiments. Anesthetized adults or larvae were homogenized for $10 \mathrm{~min}$ in $1 \mathrm{M} \mathrm{NaCl}, 20$ $\mathrm{mM}$ sodium acetate, $\mathrm{pH} 4.7$ ( $2 \mathrm{ml} / \mathrm{g}$ tissue) using a mortar and pestle. The homogenate was incubated with gentle shaking for $20 \mathrm{~min}$ at $4^{\circ} \mathrm{C}$ and centrifuged for $10 \mathrm{~min}$ at $10,000 \times \mathrm{g}$ and $4^{\circ} \mathrm{C}$. The supernatant was collected and protein concentration determined, according to the method described by Bradford (1976), using the Bio-Rad protein assay (BIO-RAD). Bovine serum albumin (Promega) was used as standard.

PG activity in the crude extracts (total protein extracts) was measured using a modified agarose diffusion assay (Taylor \& Secor, 1988; Ferrari et al., 2003). Although diffusion zones are sometimes difficult to measure with a high degree of precision, this is a very useful and widely used method of making semiquantitative assessments. Petri dishes $(90 \times 15 \mathrm{~mm})$ were filled (20 ml each) with a medium containing $100 \mathrm{mM}$ sodium acetate at different $\mathrm{pHs}(4,5,6,7$ and 8$), 0.5 \%$ polygalacturonic acid from citrus fruits (Sigma-P3850) and 0.8\% agarose (Invitrogen), mixed together and heated in a microwave. The Petri dishes were then kept at $+4^{\circ} \mathrm{C}$ until used for the assays. Crude protein extracts $(50 \mu \mathrm{g})$ were added to 5 -mm wells that had been punched in the medium and the dishes were then incubated for $12 \mathrm{~h}$ at $30^{\circ} \mathrm{C}$. Upon addition of $6 \mathrm{~N} \mathrm{HCl}$, increasing PG activity was indicated by the presence of a whitish halo of increasing diameter $(\mathrm{mm})$ around the wells.

\section{PG activity and location in Miridae}

Since PG activity in the initial investigation of different insect species was recorded mainly for mirid bugs (see Results Table 1 ), only these insects were used to measure PG activity in males and females and their location in salivary glands and guts at different pHs. The following species were tested: Lygus rugulipennis Poppius, L. pratensis (L.) and Adelphocoris lineolatus (Goeze) (Heteroptera: Miridae), which are economically among the most important mirid bugs in temperate areas.

To evaluate PG presence in females and males of the three species, whole insects were homogenized and PG activity, expressed as the halo diameter $(\mathrm{mm})$, was measured as described above at different pHs (5, 6, 7 and 8), using $15 \mu \mathrm{g}$ of crude protein extract for each species. Data were analysed separately for each species using 2-way factorial ANOVA, considering sex (males and females) and $\mathrm{pH}(5,6,7$, and 8$)$ as main effects. $F$ tests were used to assess the significance of the effects and their interactions. When the effect of sex and its interaction with $\mathrm{pH}$ were not significant, data from females and males were pooled and the means computed. If the $\mathrm{pH}$ effect was significant, the relationships between PG activity and $\mathrm{pH}$ were tested using regression analysis. The best-fitting polynomial function was estimated and $F$ tests used to calculate significance of regression terms and residuals (Sokal \& Rohlf, 1998).

For determination of PG location, salivary glands and guts of females of the three species were removed in a saline solution $(\mathrm{pH}=7.2)$ under a stereomicroscope. The head and prothorax were drawn away using forceps to expose the salivary glands and gut (Agusti \& Cohen, 2000). The salivary glands, together with ducts and accessory glands, and the whole gut were then removed and immediately cooled to $-20^{\circ} \mathrm{C}$. The salivary gland 
TABLE 1. Screening for PG activity at different $\mathrm{pHs}$, in insect species belonging to different taxa (orders and families). +: presence of PG activity; -: lack of PG activity; blank spaces: not tested. ${ }^{\mathrm{a}}$ Last instar larvae; ${ }^{\mathrm{b}}$ Botrytis cinerea Pers.

\begin{tabular}{|c|c|c|c|c|c|}
\hline \multirow{2}{*}{$\begin{array}{l}\text { Insect species } \\
\text { Heteroptera: Miridae }\end{array}$} & \multicolumn{4}{|c|}{$\overline{\mathrm{pH}} 4 \mathrm{pH} 5 \mathrm{pH} 6 \mathrm{pH} 7 \mathrm{pH} 8$} & $\frac{\text { vity }}{\mathrm{pH} 8}$ \\
\hline & & & & & \\
\hline Lygus rugulipennis Poppius & - & + & + & + & + \\
\hline Lygus pratensis (L.) & & - & + & + & + \\
\hline Orthops kalmi (L.) & & - & + & + & + \\
\hline Adelphocoris lineolatus (Goeze) & & - & + & + & + \\
\hline $\begin{array}{l}\text { Closterotomus norwegicus (Gmelin) } \\
\text { Heteroptera: Lygaeidae }\end{array}$ & & - & + & + & + \\
\hline $\begin{array}{c}\text { Metopoplax ditomoides (Costa) } \\
\text { Heteroptera: Pentatomidae }\end{array}$ & - & - & - & - & - \\
\hline Nezara viridula $(\mathrm{L})$. & - & - & - & - & - \\
\hline $\begin{array}{l}\text { Murgantia histrionica (Hahn) } \\
\text { Hemiptera: Aphididae }\end{array}$ & - & - & - & - & - \\
\hline $\begin{array}{l}\text { Aphis fabae Scopoli } \\
\text { Lepidoptera: Noctuidae }\end{array}$ & - & - & - & - & - \\
\hline $\begin{array}{l}\text { Sesamia nonagrioides (Lefèbvre) }{ }^{\text {a }} \\
\text { Coleoptera: Tenebrionidae }\end{array}$ & - & - & - & - & - \\
\hline $\begin{array}{l}\text { Tenebrio molitor }(\mathrm{L} .)^{\text {a }} \\
\text { Coleoptera: Curculionidae }\end{array}$ & - & - & - & - & - \\
\hline Sitophilus sp. & & + & + & + & - \\
\hline Control $^{\mathrm{b}}$ & + & + & + & + & + \\
\hline
\end{tabular}

complexes and gut (15 $\mu \mathrm{g}$ of total protein extract) were directly analyzed for enzyme activity using the agarose diffusion procedure, described above. Because in the previous experiment the highest activity of mirid PGs was observed at $\mathrm{pH} 7$ and 8 (see Results), assays were conducted at these $\mathrm{pH}$ conditions. Data on PG activity were then analysed separately for each species using 2-way factorial ANOVA, considering location (salivary glands and gut) and $\mathrm{pH}(7$ and 8$)$ as main effects. $F$ tests were used to assess the significance of the effects and their interactions. Data shown in graphs were pooled and the means computed considering the significance of effects and their interactions.

In addition to the above species, the salivary glands of Closterotomus norwegicus (Gmelin) females were also tested for PG activity, using $15 \mu \mathrm{g}$ of crude protein extracts. Because of the lack of material it was not possible to test the guts of field collected individuals of this univoltine species, and the data were analysed separately.

\section{Inhibition of mirid PGs by PGIPs}

The inhibitory activity of the following PGIPs from different plants was assayed using mirid PGs: PvPGIP1, PvPGIP2, PvPGIP3 and PvPGIP4, all obtained from Phaseolus vulgaris, Pinto genotype; AtPGIP1 and AtPGIP2 from Arabidopsis thaliana, Columbia genotype and GmPGIP1 and GmPGIP2 from Glycine max (kindly provided by R. D'Ovidio). These inhibitors were tested against PGs of L. rugulipennis, L. pratensis, $O$. kalmi, A. lineolatus, and C. norwegicus.

Single bean PGIPs were obtained by transient expression in Nicotiana benthamiana plants using a modified potato virus $\mathrm{X}$ (PVX) as a vector (Leckie et al., 1999; D'Ovidio et al., 2004). PvPGIP1 and PvPGIP2 of Pinto genotype were purified as described by Leckie et al. (1999), while PvPGIP3 and PvPGIP4
TABLE 2. $F$ statistics from ANOVAs of PG activity in mirid species as affected by sex (males and females) and $\mathrm{pH}(5,6,7$ and 8).

\begin{tabular}{lcccc}
\hline Mirid species & Source & $d f$ & $F$ & $P$ \\
\hline L. rugulipennis & $\mathrm{sex}$ & 1 & 0.66 & 0.429 \\
& $\mathrm{pH}$ & 3 & 8.89 & 0.001 \\
& $\mathrm{sex} * \mathrm{pH}$ & 3 & 0.04 & 0.987 \\
& $\mathrm{error}$ & 16 & & \\
\hline L. pratensis & $\mathrm{sex}$ & 1 & 5.86 & 0.028 \\
& $\mathrm{pH}$ & 3 & 40.52 & $<0.000$ \\
& $\mathrm{sex} * \mathrm{pH}$ & 3 & 0.66 & 0.588 \\
& $\mathrm{error}$ & 16 & & \\
\hline A. lineolatus & $\mathrm{sex}$ & 1 & 3.68 & 0.073 \\
& $\mathrm{pH}$ & 3 & 203.30 & $<0.000$ \\
& $\mathrm{sex} * \mathrm{pH}$ & 3 & 1.35 & 0.294 \\
& $\mathrm{error}$ & 16 & & \\
\hline
\end{tabular}

were directly used as crude protein extracts prepared from PVXinfected $N$. benthamiana leaves.

Crude extracts (total protein extracts) obtained from Arabidopsis plants overexpressing the coding sequences of either AtPGIP1 or AtPGIP2 were used to test the activity of these inhibitors (Ferrari et al., 2003).

The inhibitory activities of PGIPs were measured at $\mathrm{pH} \mathrm{7.0}$ using a modified agarose diffusion assay procedure similar to the one described above. Purified PGIPs or crude extracts containing PGIPs were added to the wells before the insect total extracts containing PGs. Only insect crude extracts were utilized as a reference for each test. The inhibitory activity was expressed as the percentage reduction in diameter $(\mathrm{mm})$ of the halos compared to those in the controls (without PGIPs).

\section{RESULTS}

\section{PG activity in insects}

All the mirid species that were tested exhibited PG activity at $\mathrm{pH}$ 6-8, with L. rugulipennis also showing activity at $\mathrm{pH} 5$ (Table 1). PG was also found in the weevil Sitophilus sp. at $\mathrm{pH} 5-7$, whereas none of the other insects exhibited PG activity at the pHs tested (Table 1). The PG from Botrytis cinerea (control) was active at $\mathrm{pH} 4-8$, although maximum activity was scored at $\mathrm{pH} 5$ (data not shown).

\section{PG activity and location in Miridae}

The effects of sex (males and females) and $\mathrm{pH}(5,6,7$ and 8 ) on PG activity were similar in the three mirid species tested. In L. rugulipennis only the $\mathrm{pH}$ effect was significant, whereas the effects of sex and the sex * $\mathrm{pH}$ interaction were not. Similar results were obtained for $A$. lineolatus, although the effect of sex was close to significant. In L. pratensis both sex and $\mathrm{pH}$ effects were significant, whereas their interaction was not (Table 2). Specifically, females of this species showed a higher enzymatic activity compared to males (Fig. 1). For regression analysis the data for males and females of L. rugulipennis and A. lineolatus were therefore pooled, whereas those for L. pratensis were not. In all cases PG activity followed a quadratic function of $\mathrm{pH}$, with the highest values at $\mathrm{pH}$ 7-8 (Fig. 1). 

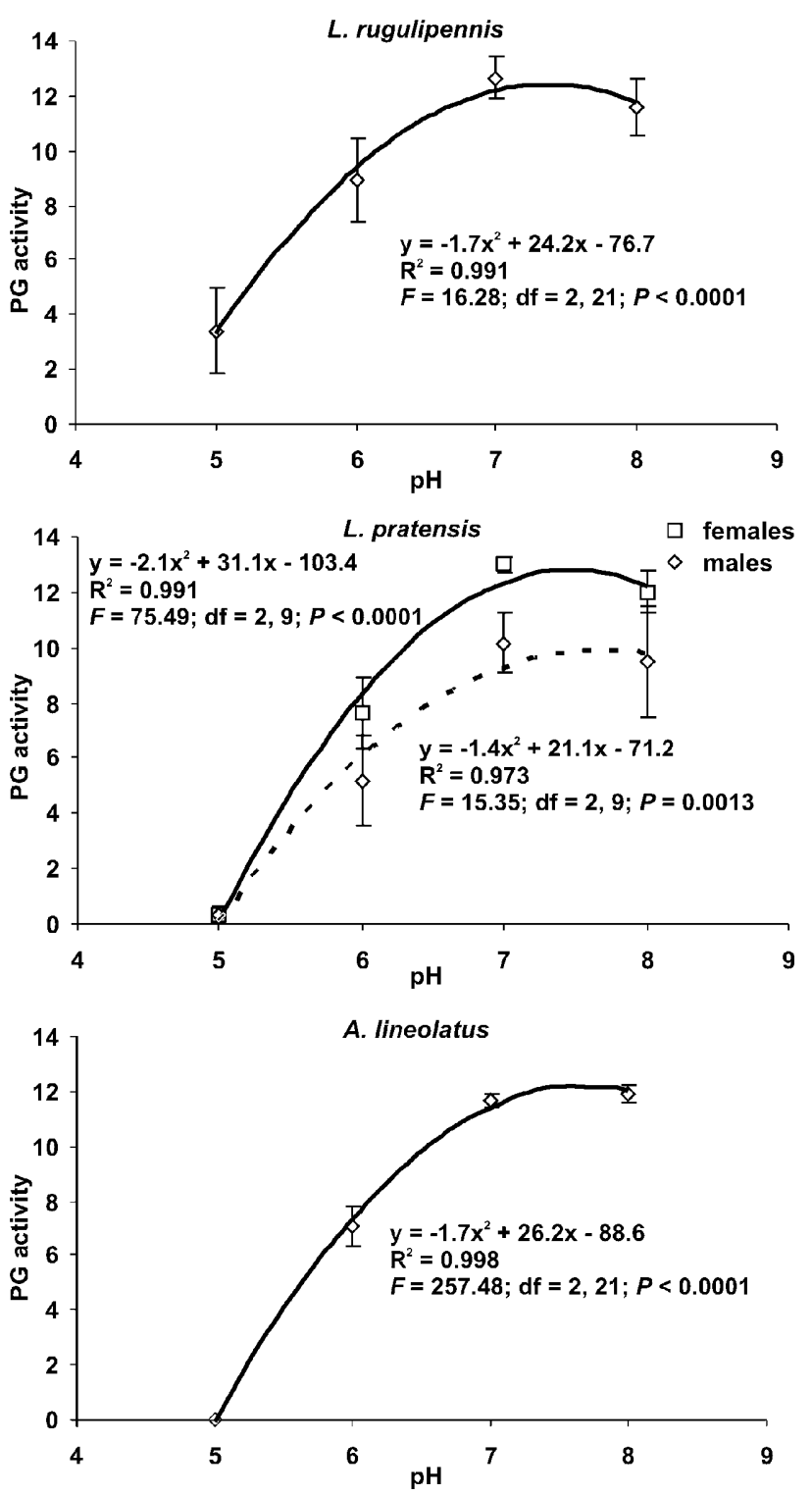

Fig. 1. Relationship between PG activity (halo diameter in $\mathrm{mm}$; Mean $\pm \mathrm{SE}$ ) and $\mathrm{pH}$ in Lygus rugulipennis, Lygus pratensis and Adelphocoris lineolatus.

The location of the PG (salivary glands and gut) in the three mirid species was also determined at different $\mathrm{pH}$, but because previously, the highest activity was recorded at $\mathrm{pH} 7$ and 8, only these conditions were used. The $\mathrm{pH}$ did not affect the results and the interactions of $\mathrm{pH} *$ location were not significant. The location effect was significant in all species, with the highest activity in the salivary glands (Table 3, Fig. 2).

PG activity in the salivary glands of female $C$. norwegicus was evaluated at $\mathrm{pH} 7$ and 8 , and in crude extracts of female $O$. kalmi at $\mathrm{pH}$ 7. The diameter of the halo in the case of $C$. norwegicus was $10.66 \pm 0.66 \mathrm{~mm}(\mathrm{pH}=7)$ and $11.16 \pm 0.92(\mathrm{pH}=8)$, and for $O$. kalmi $8.00 \pm 1.00$ $\mathrm{mm}($ Mean $\pm \mathrm{SE})$.
TABLE 3. $F$ statistics from ANOVAs of PG activity in mirid species as affected by location (salivary glands and gut) and $\mathrm{pH}$ (pH 7 and 8).

\begin{tabular}{lccrc}
\hline Mirid species & Source & $d f$ & $F$ & $P$ \\
\hline L. rugulipennis & location & 1 & 21.50 & 0.002 \\
& $\mathrm{pH}$ & 1 & 0.03 & 0.874 \\
& location $* \mathrm{pH}$ & 1 & 0.15 & 0.712 \\
& error & 8 & & \\
\hline L. pratensis & location & 1 & 41.75 & $<0.001$ \\
& $\mathrm{pH}$ & 1 & 0.49 & 0.503 \\
& location $* \mathrm{pH}$ & 1 & 0.01 & 0.940 \\
& error & 8 & & \\
\hline A. lineolatus & location & 1 & 16.59 & 0.004 \\
& $\mathrm{pH}$ & 1 & 0.19 & 0.674 \\
& location $* \mathrm{pH}$ & 1 & 0.02 & 0.889 \\
& error & 8 & & \\
\hline
\end{tabular}

\section{Inhibition of mirid PGs by PGIPs}

Two of the PGIPs from bean, PvPGIP3 and PvPGIP4, inhibited all the mirid PGs tested, with the inhibitory activity ranging from $\sim 10 \%$ to $\sim 42 \%$ (Table 4 ). In contrast, PvPGIP1 and PvPGIP2 were not active against mirid PGs although they are strong inhibitors of B. cinerea and other fungal PGs (D'Ovidio et al., 2004). Similarly, none of the other PGIPs tested were active against mirid PGs (Table 4).

\section{DISCUSSION}

Several species of insects belonging to different taxa are known to produce polygalacturonases. In our investigation of chewing insects, belonging to Noctuidae, Tenebrionidae and Curculionidae, PG activity was found only in the weevil Sitophilus sp., which confirms previous reports. PGs have been isolated from the guts of weevils (Shen et al., 1996; Doostdar et al., 1997) and a sequence for putative pectinase was obtained from Chrysomelidae (Girard \& Jouanin, 1999). Their function was thought to be related to the digestion of plant material. Although early papers hypothesized that these enzymes were synthesized by symbiotic microorganisms present in the guts of insects, recent research has shown that a PG from Sitophilus oryzae (L.) is encoded in the insect's genome and expressed at the level of gut epithelium (Shen et al., 2003).

Among piercing-sucking species, no PG activity was found in Metopoplax ditomoides (Heteroptera: Lygaeidae), Nezara viridula (L.) (Heteroptera: Pentatomidae) or Aphis fabae Scopoli (Hemiptera: Aphididae), although PGs have been recorded for other aphid species (Adams \& McAllan, 1956; Laurema \& Nuorteva, 1961; Miles, 1972; Campbell \& Dreyer, 1985; Ma et al., 1990; Tjallingii \& Esch, 1993; Miles, 1999; Cherqui \& Tjallingii, 2000).

Our analyses confirm the presence of PGs in L. rugulipennis (Laurema et al., 1985; D’Ovidio et al., 2004) and $A$. lineolatus (D'Ovidio et al., 2004) and record PGs for the first time in the mirid species, L. pratensis, O. kalmi 


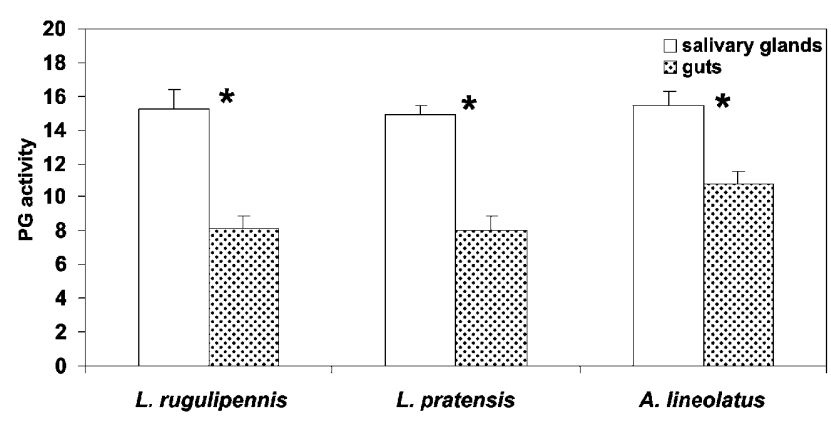

Fig. 2. Comparison of PG activity (halo diameter in $\mathrm{mm}$; Mean $\pm \mathrm{SE}$ ) of the salivary glands and guts of Lygus rugulipennis, Lygus pratensis and Adelphocoris lineolatus (* $p<0.05 ; t$ test).

(L.) and C. norwegicus. Endo-PGs (and occasionally exoPGs), secreted by the salivary glands, appear to be common in the Miridae, the largest heteropteran family, in terms of number of species (Laurema \& Nuorteva, 1961; Strong \& Kruitwagen, 1968; Strong, 1970; Miles, 1972; Laurema et al., 1985; Martin et al., 1988; Agblor et al., 1994; Cohen \& Wheeler, 1998; Agusti \& Cohen, 2000; Boyd et al., 2002; D’Ovidio et al., 2004; Shackel et al., 2005; reviewed by Wheeler, 2001). Mirid saliva also contains amylases and proteases and some minor enzymes; however PGs are closely associated with the lacerate-and-flush feeding strategy typical of mirids and appear to be the major cause of damage to plants (reviewed by Wheeler, 2001). A recent paper clearly shows that micro-injections of partially purified PGs from a Nearctic Lygus sp. result in plant injuries similar to those caused by Lygus feeding (Shackel et al., 2005), confirming the hypothesis that mirid PGs cause the development of much larger lesions than result from simple mechanical damage or feeding by other sap-sucking insects (Strong, 1970; Wheeler, 2001). This is the main reason for the economic importance of Miridae. Phytophagous and phytozoophagous mirid bugs are known to damage both vegetative and reproductive organs of innumerable herbaceous and woody plants, and are major crop pests in the temperate regions and the tropics (Conti \& Bin, 2001; reviewed by Wheeler, 2001).
Most Miridae embed their eggs in plant tissues using a sharp ovipositor. Another possible function of the PGs in mirid saliva, proposed on the basis of this characteristic and the oviposition sequence, has been described for some species. Before oviposition, female bugs insert their stylets into plants substrate apparently to initiate a hole, which is enlarged for egg laying using the ovipositor (reviewed by Wheeler, 2001). PGs might be employed by phytophagous and zoophagous mirid bugs to soften plant material before oviposition (Boyd et al., 2002). However, the detailed behavioural (Conti et al., 2002; E. Conti, G. Salerno, F. Frati and F. Bin, unpubl.) and morphofunctional (Romani et al., 2005) studies of the oviposition behaviour of L. rugulipennis indicate that stylet insertion is linked to substrate examination. Therefore, a combination of both functions, i.e. substrate examination and softening, is possible.

In addition to salivary glands, PG was found also in the guts of L. rugulipennis, L. pratensis and A. lineolatus, although the activity was always lower than in saliva. Similar results were found for other mirid species, when guts were tested in addition to salivary glands (Agusti \& Cohen, 2000; Boyd et al., 2002; Boyd, 2003). Whether the gut PGs originate from the gut, or from salivary glands, has yet to be ascertained. However, mirid bugs as well as other Heteroptera, are characterized by extra-oral digestion, which results in the ingestion of partially macerated plant tissues together with salivary enzymes (Cohen, 1998; Agusti \& Cohen, 2000; Wheeler, 2001). Therefore, a salivary origin of the PGs found in the gut is to be expected.

As PGs are involved in feeding, they were found in both sexes of mirids. However, although there were no significant differences in PG activity between the sexes in L. rugulipennis and $A$. lineolatus, females of $L$. pratensis showed a higher PG activity compared to males. Because previous reports do not distinguish between PG activity in males and females, no literature data are available for comparison. In any case, an explanation for the above results may be the pre-oviposition stylet probing of the substrate (Wheeler, 2001; Boyd et al., 2002; Conti et al., 2002; Romani et al., 2005; Conti et al., unpubl. data). The higher PG activity in females may therefore be ascribed

TABLE 4. Inhibitory activity (\% mean reduction in halo diameter in $\mathrm{mm} \pm \mathrm{SEM}$ ) of PGIPs of Phaseolus vulgaris, Pinto genotype, (PvPGIP1, PvPGIP2, PvPGIP3 and PvPGIP4), Arabidopsis thaliana (AtPGIP1 and AtPGIP2) and Glycine max (GmPGIP1 and GmPGIP2) against PGs of Miridae (L. rugulipennis, L. pratensis, A. lineolatus and C. norwegicus: $\mathrm{n}=3 ;$ O. kalmi: $\mathrm{n}=1$ ). ${ }^{\text {a }}$ Total protein extracts $(15 \mu \mathrm{g})$ prepared from the indicated insect species were assayed at $\mathrm{pH}$ 7.0. Ten $\mu \mathrm{g}$ of total proteins were used for $L$. pratensis. ${ }^{\mathrm{b}}$ Purified protein. Amount of PGIP tested is in brackets. ${ }^{\mathrm{c}}$ Crude extract from PVX-infected N. benthamiana plants. Amount of total proteins tested is in brackets. A crude extract prepared from plants infected with "empty" PVX, as a control, did

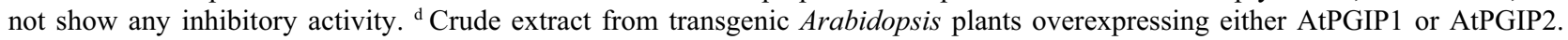
Amount of total protein tested is in brackets. Blank spaces: not tested.

\begin{tabular}{lcccccccc}
\hline Polygalacturonase $^{\mathrm{a}}$ & $\begin{array}{c}\text { PvPGIP1 } \\
(1.5 \mu \mathrm{g})^{\mathrm{b}}\end{array}$ & $\begin{array}{c}\text { PvPGIP2 } \\
(1.5 \mu \mathrm{g})^{\mathrm{b}}\end{array}$ & $\begin{array}{c}\text { PvPGIP3 } \\
(7 \mu \mathrm{g})^{\mathrm{c}}\end{array}$ & $\begin{array}{c}\text { PvPGIP4 } \\
(7 \mu \mathrm{g})^{\mathrm{c}}\end{array}$ & $\begin{array}{c}\text { AtPGIP1 } \\
(3 \mu \mathrm{g})^{\mathrm{d}}\end{array}$ & $\begin{array}{c}\text { AtPGIP2 } \\
(3 \mu \mathrm{g})^{\mathrm{d}}\end{array}$ & $\begin{array}{c}\text { GmPGIP1 } \\
(15 \mu \mathrm{g})^{\mathrm{c}}\end{array}$ & $\begin{array}{c}\text { GmPGIP2 } \\
(15 \mu \mathrm{g})^{\mathrm{c}}\end{array}$ \\
\hline L. rugulipennis & 0 & 0 & $37.88 \pm 8.3$ & $42.22 \pm 4.33$ & 0 & 0 & 0 & 0 \\
L. pratensis & & & $26.89 \pm 1.4$ & $24.46 \pm 0.61$ & & & & \\
O. kalmi & & & 34.0 & 50.0 & & & 0 & 0 \\
A. lineolatus & 0 & 0 & $23.35 \pm 15.62$ & $33.43 \pm 5.28$ & 0 & 0 & 0 & 0 \\
C. norwegicus & 0 & 0 & $21.13 \pm 8.3$ & $9.9 \pm 5.55$ & 0 & 0 & 0 & 0 \\
\hline
\end{tabular}


not only to the larger amount of food they require compared to males (Cohen \& Tang, 1997; Zeng \& Cohen, 2000) but also to additional saliva production for preovipositional stylet probing. The differences recorded between $L$. pratensis and the other two species may depend on differences in their physiology. However, more research is needed in order to test this hypothesis.

An important factor affecting $\mathrm{PG}$ activity is $\mathrm{pH}$. The three species of mirid tested at different $\mathrm{pH}$, L. rugulipennis, A. lineolatus and L. pratensis, show maximum activity at $\mathrm{pH} 7-8$ and minimum or no activity at $\mathrm{pH} 5$. However, some papers data show that the PGs of Lygus spp. are optimally active at acidic pH (Laurema et al., 1985; Agblor et al., 1994). This inconsistency between our results and those in the literature may be explained by the different methods used to evaluate PG activity.

Little information is available on the inhibition of the activity of insect PGs by the PGIPs of different plants. A PG from the gut of a plant-chewing insect, Diaprepes abbreviatus L. (Coleoptera: Curculionidae), is inhibited in vitro by an orange PGIP (Doostdar et al., 1997). More recently, bean PGIPs were clearly demonstrated to inhibit PGs of piercing-sucking insects, specifically L. rugulipennis, A. lineolatus (Heteroptera: Miridae) (D’Ovidio et al., 2004) and a Nearctic Lygus sp. (Shackel et al., 2005). Here the data reported for L. rugulipennis and A. lineolatus (D'Ovidio et al., 2004) are confirmed and similar evidence for other species is presented, i.e., L. pratensis, $O$. kalmi and C. norwegicus. The other PGIPs tested were not active. These results, together with the inhibition of PGs from a Lygus sp. by PGIPs from alfalfa and cotton (Shackel et al., 2005), suggest that inhibition of mirid PG by plant PGIPs is not exceptional. Quantitative evaluation indicates that PGIP inhibitory activity against mirid PGs is generally weaker than that of fungal $P G$, but this may depend on the experimental conditions (D'Ovidio et al., 2004).

The presence of PGs in weevils, mirids and few other insect species, and their absence in more primitive animal taxa raises the question of how during evolution insects acquired this enzymatic function. Intriguingly, the PG sequences of the rice weevil, S. oryzae (Shen et al., 2003) and mustard beetle, Phaedon cochleariae F. (Markovic \& Janecek, 2001) indicate that these are more closely related to fungal PGs, leading to the hypothesis of a fungal origin of the PG genes in these insects and possible acquisition by horizontal gene transfer (Shen et al., 2003). The ability of PGIPs to inhibit PGs of fungi, weevils and mirids, but not those of plants and bacteria, conforms with degree of similarity between the enzymes of these organisms.

In plants, PGIPs are up-regulated in response to stressrelated signals, wounding and attack by fungi (De Lorenzo et al., 2001). A PGIP gene from Brassica napus L. (Bnpgip1) is strongly induced by the attack of a chewing insect (flea beetle) and mechanical wounding. However, this response is a generic reaction of the plant against opportunistic microorganisms at the site of wound (Li et al., 2003) rather than a specific response aimed at inhibiting insect PGs.
The expression of PGIP genes in several plants is regulated by salicylic and/or jasmonic acids (Ferrari et al., 2003; Li et al., 2003), two endogenous signals known to induce plant defence (Dicke et al., 1999; Walling, 2000; Ferry et al., 2004). The same metabolic pathways also occur as part of the so-called plant indirect induced defences against herbivorous insects, leading to the emission of plant volatiles (induced synomones) that attract the natural enemies of the herbivores (Paré \& Tumlinson, 1997; Dicke et al., 1999; Dicke \& van Loon, 2000). Cotton plants attacked by the piercing-sucking species $L$. hesperus emit volatile signals that attract the egg parasitoid, Anaphes iole Girault, of this bug (Rodriguez-Saona et al., 2002; Manrique et al., 2005), although the metabolic pathways involved in this response have not yet been characterized.

Herbivory by Lygus and other mirid bugs, therefore, may induce two different types of plant defence, direct through PGIPs and indirect through volatile synomones. If this is confirmed, our results will provide useful basic information for producing of plants with greater resistance against insects, and pathogens (D'Ovidio et al., 2004; Shackel et al., 2005).

ACKNOWLEDGEMENTS. We are grateful to L. Chiattelli and D. Marchionni for help in collecting and rearing the insects. This work was financially supported by MIUR - Programmi di Ricerca Scientifica di Rilevante Interesse Nazionale (PRIN) "Direct and indirect defences in crop plants for a sustainable control of insect pests", no. 2004075974.

\section{REFERENCES}

Adams J.B. \& McAllan J.W. 1956: Pectinase in the saliva of Myzus persicae (Sulz.) (Homoptera: Aphididae). Can. J. Zool. 34: 541-543.

Agblor A., Henderson H.M. \& Madrid F.J. 1994: Characterisation of alpha-amylase and polygalacturonase from Lygus spp. (Heteroptera: Miridae). Food Res. Int. 27: 321-326.

Agusti N. \& Cohen A. 2000: Lygus hesperus and L. lineolaris (Hemiptera: Miridae): the salivary and midgut enzymes. $J$. Entom. Sci. 35: 176-182

Bellincampi D., Camardella L., Delcour J.A., Desseaux V., D’Ovidio R., Durand A., Elliot G., Gebruers K., Giovane A., Juge N., Sÿ J.F., Svensson B. \& Vairo D. 2004: Potential physiological role of plant glycosidase inhibitors. Biochim. Biophy. Acta 1696: 265-274.

BoYD D.W. JR. 2003: Digestive enzymes and stylet morphology of Deraeocoris nigritulus (Uhler) (Hemiptera: Miridae) reflect adaptations for predatory habits. Ann. Entomol. Soc. Am. 96: 667-671.

Boyd D.W. JR., Cohen A.C. \& Alverson D.R. 2002: Digestive enzymes and stylet morphology of Deraeocoris nebulosus (Hemiptera: Miridae), a predacious plant bug. Ann. Entomol. Soc. Am. 95: 395-401.

BRADFORD M.M. 1976: A rapid sensitive method for the quantisation of microgram quantities of protein utilising the principle of protein-dye binding. Anal. Biochem. 72: 248-254.

Campbell B.C. \& Dreyer D.L. 1985: Host-plant resistance of sorghum: differential hydrolysis of sorghum pectic substances by polysaccharases of greenbug biotypes (Schizaphis graminum, Homoptera: Aphididae). Arch. Insect Biochem. 2: 203-215. 
Cherqui A. \& TJallingiI W.F. 2000: Salivary proteins of aphids, a pilot study on identification, separation and immunolocalisation. J. Insect Physiol. 46: 1177-1186.

CoHen A.C. 1998: Solid-to-liquid feeding: the inside(s) story of extra-oral digestion in predaceous Arthropoda. Am. Entomol. 44: $103-117$.

CoHen A.C. \& TANG R. 1997: Relative prey weight influences handling time and biomass extraction in Sinea confusa and Zelus renardii (Heteroptera: Reduviidae). Environ. Entomol. 26: $559-565$.

Cohen A.C. \& Wheeler A.G. JR. 1998: Role of saliva in the highly destructive fourlined plant bug (Hemiptera: Miridae: Mirinae). Ann. Entomol. Soc. Am. 91: 94-100.

Conti E. \& BIN F. 2001: Native Lygus spp. (Heteroptera: Miridae) damaging introduced Hibiscus cannabinus in Italy. $J$. Econ. Entomol. 94: 648-657.

Conti E., Salerno G. \& Bin F. 2002: Oviposition strategies of Lygus rugulipennis (Hemiptera: Miridae). ESA Annual Meeting, Fort Lauderdale, Florida, USA, 2002. p. 38 (abstract, http://esa.confex.com/esa/2002/techprogram/paper_7534.htm)

Conti E., Frati F., Galletti R., Salerno G., Bin F. \& De Lorenzo G. 2004: Mirid bug polygalacturonases (PGs) are inhibited by cell wall proteins (PGIPs), indicating potential for induced resistance in plants. 12th International Symposium on Insect-Plant Relationships, 2004, Berlin, Germany. (Abstract) p. 130.

De Lorenzo G. \& Ferrari S. 2002: Polygalacturonase inhibiting proteins in defence against phytopathogenic fungi. Curr. Opin. Plant Biol. 5: 295-299.

De Lorenzo G., Castoria R., Bellincampi D. \& Cervone F. 1997: Fungal invasion enzymes and their inhibition. In Carroll G. \& Tudzynski P. (eds): The Mycota. Springer, Berlin, pp. 61-83.

De Lorenzo G., D’Ovidio R. \& Cervone F. 2001: The role of polygalacturonase-inhibiting proteins (PGIPs) in defence against pathogenic fungi. Annu. Rev. Phytopathol. 39: 313-335.

Dicke M., Gols R., Ludeking D. \& Posthumus M.A. 1999: Jasmonic acid and herbivory differentially induces carnivoreattracting plant volatiles in lima bean plants. J. Chem. Ecol. 25: 1907-1922.

DiCKE M. \& VAN LOON J.J.A. 2000: Multitrophic effects of herbivore-induced plant volatiles in an evolutionary context. Entomol. Exp. Appl. 97: 237-249.

Doostdar H., Mc Collum T.G. \& Mayer R.T. 1997: Purification and characterization of an endo-polygalacturonase from the gut of West Indies sugarcane rootstalk borer weevil (Diaprepes abbreviatus L.) larvae. Comp. Biochem. Phys. (B) 118: 861-867.

D’Ovidio R., Raiola A., Capodicasa C., Devoto A., Pontiggia D., Roberti S., Galletti R., Conti E., O’Sullivan D., De Lorenzo G. 2004: Characterization of the complex locus of Phaseolus vulgaris encoding polygalacturonase-inhibiting proteins (PGIPs) reveals sub-functionalization for defence against fungi and insects. Plant Physiol. 135: 2424-2435.

Ferrari S., Vairo D., Ausubel F.M., Cervone F. \& De Lorenzo G. 2003: Tandemly duplicated Arabidopsis genes that encode polygalacturonase-inhibiting proteins are regulated coordinately by different signal trasduction pathways in response to fungal infection. Plant Cell 15: 93-106.

Ferry N., Edwards M.G., Gatehouse J.A. \& Gatehouse A.M.R. 2004: Plant-insect interactions: molecular approaches to insect resistance. Curr. Opin. Biotech. 15: 155-161.

Giacometti R. 1995: Rearing of Sesamia nonagrioides Lefèbvre on a meridic diet (Lepidoptera: Noctuidae). Redia 78: 19-27.
GiRARD C. \& JouAnIN L. 1999: Molecular cloning of cDNAs encoding a range of digestive enzymes from the phytophagous beetle Phaedon cochleariae. Insect Biochem. Molec. 29: $1129-1142$.

Jaubert S., Laffaire J.-B., Abad P. \& Rosso M.-N. 2002: A polygalacturonase of animal origin isolated from the rootknot nematode Meloidogyne incognita. FEBS Letters 522: 109-112.

Laurema S. \& Nuorteva P. 1961: On the occurrence of pectic polygalacturonase in the salivary glands of Heteroptera and Homoptera Auchenorrhyncha. Ann. Entomol. Fenn. 27: 89-93.

Laurema S., Varis A.L. \& Miettinen H. 1985: Studies on enzymes in the salivary glands of Lygus rugulipennis (Hemiptera: Miridae). Insect Biochem. 15: 211-224.

Li R., Rimmer R., Yu M., Sharpe A.G., Seguin-Swartz G., Lydiate D. \& Hegedus D.D. 2003: Two Brassica napus polygalacturonase inhibitory protein genes are expressed at different levels in response to biotic and abiotic stresses. Planta 217: 299-308.

Leckie F., Mattei B., Capodicasa C., Hemmings A., Nuss L., Aracri B., De Lorenzo G. \& Cervone F. 1999: The specificity of polygalacturonase-inhibiting protein (PGIP): a single amino acid substitution in the solvent-exposed beta-trand / beta-turn region of the leucine-rich repeats (LRRs) confers a new recognition capability. EMBO J. 18: 2352-2363.

Ma R., Reese H.C., Black W.C. \& Bramel-Cox P. 1990: Detection of pectinesterase and polygalacturonase from salivary secretions of living greenbugs, Schizaphis graminum (Homoptera: Aphididae). J. Insect Physiol. 36: 507-512.

Manrique V., Jones W.A., Williams III L.H. \& Bernal J. 2005: Olfactory responses of Anaphes iole (Hymenoptera: Mymaridae) to volatile signals derived from host habitat. $J$. Insect Behav. 18: 89-104.

Markovic O. \& JANECEK S. 2001: Pectin degrading glycoside hydrolases of family 28: sequence-structural features, specificities and evolution. Protein Engin. 14: 615-631.

Martin W.R.Jr., Morgan P.W., Sterling W.L. \& Meola R.W. 1988: Stimulation of ethylene production in cotton by salivary enzymes of the cotton fleahopper (Heteroptera: Miridae). Environ. Entomol. 17: 930-935.

Miles P.W. 1972: The saliva of Hemiptera. Adv. Insect Physiol. 9: $183-255$

Miles P.W. 1999: Aphis saliva. Biol. Rev. 74: 41-85.

Paré P.W. \& Tumlinson J.H. 1997: Induced synthesis of plant volatiles. Nature 385: 30-31.

Ridley B.L, O’Neill M.A. \& Mohnen D. 2001: Pectins: structure, biosynthesis, and oligogalacturonide-related signaling. Phytochemistry 57: 929-67

Rodriguez-Saona C., Crafts-Brandner S.J., Williams III L. \& PARÉ P.W. 2002: Lygus hesperus feeding and salivary gland extracts induce volatile emissions in plants. J. Chem. Ecol. 28: $1733-1747$.

Romani R., Salerno G., Frati F., Conti E., Isidoro N. \& Bin F. 2005: Oviposition behaviour in Lygus rugulipennis: a morpho-functional study. Entomol. Exp. Appl. 115: 17-25.

Shackel K.A., de la paz Celorio-Mancerio M., Ahmadi H., Greve L.C., Teuber L.R., Backus E.A. \& Labavitch J.M. 2005: Micro-injection of Lygus salivary gland proteins to simulate feeding damage in alfalfa and cotton flowers. Arch. Insect Biochem. Physiol. 58: 69-83.

Shen Z., Reese J.C. \& Reeck G. 1996: Purification and characterization of polygalacturonase from the rice weevil, Sitophilus oryzae (Coleoptera: Curculionidae). Insect Biochem. Molec. 26: 427-433. 
Shen Z., Denton M., Mutti N., Pappan K., Kanost M.R., Reese J.C. \& REECK G.R. 2003: Polygalacturonase from Sitophilus oryzae: possible horizontal transfer of a pectinase gene from fungi to weevils. J. Insect Sci. 3: 24-32.

SoKal R. \& RohlF F.J. 1998: Biometry. Freeman W.H., New York, $887 \mathrm{pp}$.

STrong F.E. 1970: Physiology of injury caused by Lygus hesperus. J. Econ. Entomol. 63: 808-814.

Strong F.E. \& Kruitwagen E.C. 1968: Polygalacturonase in the salivary apparatus of Lygus hesperus (Hemiptera). J. Insect Physiol. 14: 1113-1119.

TAYlor R.J. \& Secor G.A. 1988: An improved diffusion assay for quantifying the polygalacturonase content of Envinia culture filtrates. Phytopathology 78: 1101-1103.
TJALLINGII W.F. \& EsCH T.H. 1993: Fine structure of aphid stylet routes in plant tissues in correlation with EPG signals. Physiol. Entomol. 3: 317-328.

WALLING L.L. 2000: The myriad plant responses to herbivores. J. Plant Growth Regul. 19: 195-216.

WheELER A.G.JR 2001: Biology of the Plant Bugs. Cornell University Press, Ithaca, New York, $506 \mathrm{pp}$.

ZENG F. \& CoHEN A.C. 2000: Comparison of $\alpha$-amylase and protease activities of a zoophytophagous and two phytozoophagous Heteroptera. Comp. Biochem. Phys. (A) 126: 101-106.

Received September 9, 2005; revised and accepted December 12, 2005 